\section{FIRST REPORT OF BARLERIA LUPULINA LINDL. (ACANTHACEAE) FROM SOUTHERN INDIA}

\section{R. Vijaya Sankar and K. Ravikumar}

Foundation for Revitalisation of Local Health Traditions, \# 74/2, Jarakabande Kaval, Post Attur, Yelahanka via, Bangalore, Karnataka 560064, India.

Email: r.vijayasankar@frlht.org.in

web supplement

\section{Barleria lupulina Lindl.}

In Edwards, Bot. Reg. 18: t. 1483. 1832-1833; C.B. Clarke in Hook. f., Fl. Brit. India 4: 482. 1884; Cooke, Fl. Pres. Bombay 2: 464. 1967 (Rept.ed.); K.K. Khanna et al. in V. Mudgal et al. (eds.), Fl. Madhya Pradesh 2: 292. 1997; P.K. Bhattacharyya \& Krishnendu Sarkar, Fl. W. Champaran, Bihar. 331. t. 332. 1998; L.H. Cramer in Dassan. et al. (eds.), Rev. Handb. Fl. Ceylon 12: 92. 1998. (Acanthaceae).

\section{Common names}

Semmulli, Mullu kanagaambaram (Tamil).

\section{Materials examined}

10.ix.2000, Kothavalampatty Village, Kulathur Taluk, Pudukkottai District, coll. N. Ganapathy, 26547, $\pm 110 \mathrm{~m}$; 29.ix.2000, Meyyur Village, Tiruvannamalai District, coll. P. Durai, 37529, $\pm 230 \mathrm{~m}$; 23.ii.2004, Auroville, Pichandikulam, Villupuram District, coll. K. Ravikumar, 59351, $\pm 20 \mathrm{~m}$. All the voucher specimens and plant images are deposited in the herbarium of FRLHT (acronym 'FRLH') and the image library respectively.

\section{Diagnosis}

Spiny undershrubs, up to $1.5(3) \mathrm{m}$ high. Leaves narrowly oblong-lanceolate, 4-13 x 1-2cm, subcoriaceous, glabrous, cuneate at base, obtuse at apex, spine-tipped; cystoliths linear, densely irregularly scattered, prominent above; midrib prominent, sulcate, reddish; lateral nerves indistinct; petioles ca $5 \mathrm{~mm}$ long; leaves of axillary branches oblanceolate, $c a 3.5 \mathrm{x}$ $1 \mathrm{~cm}$, base attenuate, apex obtuse-mucronate; spines two per axil, each $c a 1.5 \mathrm{~cm}$ long, whitish, deflexed. Spikes terminal, erect, strobiliform, dense, $5-7 \times 1.5-2 \mathrm{~cm}$, puberulous; bracts broadly ovate, $c a 1.5 \times 1 \mathrm{~cm}$, puberulous, with many cupular brown glands on the back at lower half, apex broadly acute, mucronate, margin ciliolate, upper half brownish; bracteoles oblanceolate, ca $5 \times 1.5 \mathrm{~mm}$, mucronulate. Flowers $c a 2.5 \mathrm{~cm}$ across; calyx-lobes four, dissimilar; two broadly ovatelanceolate, $c a 1 \times 0.4 \mathrm{~cm}$, other two linear-lanceolate, $c a 1 \mathrm{x}$ $0.2 \mathrm{~cm}$, puberulous, shortly aristate; corolla tubular, yellow; tube $\mathrm{ca} 2 \mathrm{~cm}$ long, slightly bent at base, broadening above, puberulous without; stamens two, exserted; style $c a 2.5 \mathrm{~cm}$ long, sparsely pubescent at base, glabrous above; stigma simple. Capsules clavate, compressed, $c a 1 \times 0.4 \mathrm{~cm}$, glabrous, with a solid base. Flowering - March to April; fruiting - April to September. Images 1 and $2^{\mathrm{w}}$ are herbarium specimen and the plant in the wild respectively.

\section{Remarks}

This species is native of Mauritius. In India, it has been recorded in the states of Uttar Pradesh (Rajagopal \& Panigrahi, 1965; Sharma \& Pandey, 1984), Bihar (Haines, 1922), Orissa (Haines, 1922) and Madhya Pradesh (Khanna et al., 1997) where it is reported to be running wild and occasionally planted also. This species has not been recorded so far from the southern Indian states of Goa, Karnataka, Kerala, Tamil Nadu and Andhra Pradesh. In Maharashtra, it is reported to be grown occasionally in gardens (Cooke, 1967) and there is no other further records in the recent floras of the state. In Sri Lanka, it is cultivated as a hedge plant (Cramer, 1998).

Recently, it has been collected from Pudukkottai, Sivagangai, Tiruchirappalli and Tiruvannamalai districts of Tamil Nadu. It is observed that this species is wild in Pachchaimalai Hills of Tiruchirappalli District (Charles, pers. comm.). It is planted in the demogardens of Gandeepam MPCP in Sivagangai District and Pichandikulam MPCP, Auroville, Villupuram District, Tamil Nadu, where it has reached a height of about $3 \mathrm{~m}$. It is found wild in wastelands and along waysides near Meyyur Village in Tiruvannamalai District and near Kothavalampatty Village in Pudhukkottai District.

\section{REFERENCES}

Cooke, T. (1967). The Flora of the Presidency of Bombay. Vol. 2. 464pp. (Repr. ed.)..

Cramer, L.H (1998). Acanthaceae, pp. 92. In: Dassanayake, M.D. and W.D. Clayton (editors). A Revised Handbook to the Flora of Ceylon. Vol. 12, 390pp.

Khanna, K.K., A.K. Tripathi and V. Mudgal (1997). Acanthaceae, pp. 292-293. In: Mudgal, V., K.K. Khanna and P.K. Hajra (editors). Flora of Madhya Pradesh. Vol. 2. $681 \mathrm{pp}$.

Haines, H.H (1922). The Botany of Bihar and Orissa. Bishen Singh Mahendra Pal Singh, Dehra Dun, Part 4, 682pp.

Rajagopal, T. and G. Panigrahi (1965). 'Aliens' naturalised in the Flora of Allahabad. Proceedings of the National Academy of Science, India Sec. B, 35(4): 411-422.

Sharma, B.D. and D.S. Pandey (1984). Exotic flora of Allahabad District. Flora of India Series-IV. Botanical Survey of India, Calcutta. $94 \mathrm{pp}$

\section{ACKNOWLedgements}

The authors wish to thank the Botanists at MPCPs (Medicinal Plants Conservation Parks) of Shanthimalai Trust (SRDT), Tiruvannamalai; Andhyodhaya Sangh (ANSA), Tiruchirappalli; Peoples Agricultural Farm (PAF), Pudhukkottai and Pichandikulam, Auroville, Tamil Nadu, for their valuable information and help in collection of the species.

${ }^{w}$ See Images $1 \& 2$ on the web at www.zoosprint.org 